\title{
MANAGING KNOWLEDGE AT THE TIME OF ARTIFICIAL INTELLIGENCE: AN EXPLORATIVE STUDY WITH KNOWLEDGE WORKERS
}

\author{
Amelia Manuti \\ https://orcid.org/0000-0001-5308-7494 \\ Scopus Author ID: $\underline{38862224500}$ \\ amelia.manuti@uniba.it \\ University of Bari Aldo Moro, Italy \\ Dalila Monachino \\ https://orcid.org/0000-0001-8609-5167 \\ dalila.monachino@uniba.it \\ University of Bari Aldo Moro, Italy
}

Received September 9, 2020; Revised November 2, 2020; Accepted December 4, 2020

\begin{abstract}
In the evolutionary context of Industry 4.0, where machine learning and machine to machine technology are powerful tools for the maintenance and replicability of knowledge, the implementation of hybrid systems based on the use of Artificial Intelligence (AI) represents the key to organizational innovation and to the capitalization of knowledge. At the same time, the benefits of digital transformation for individuals and teams are often not so clear - and uncertainty surrounding the future often results in fear in those being impacted. Humans feel fear of changes to their job, fear of a job role change, job losses, being faced with learning new skills, new technology or new ways of working. Therefore, to secure the transition to the digitization organizations need to carefully support their human resources and to provide them with the reasons why they need to commit to change. In this perspective, the study aimed to investigate how high-qualified knowledge workers cope with this new situation. Yet, participants were a group of project managers, employed in some knowledge-based organizations, in which AI and digitalization systems are going to be introduced to improve replicability, circulation and storage of knowledge. The choice of this peculiar target of participants was guided by the acknowledgement of their important role within the organization, being project managers generally considered as agents of change. In view of the above, the main goal was to collect project managers' expectations and fears about the upcoming integration of secularized company flows with performing process automation strategies. In-depth individual interviews were conducted and diatextual analysis was used to approach the discursive data collected. Results showed interesting insights both in terms of organizational management implications as well as of future research development. Participants showed clear awareness about the need to "go digital" to improve organizational performance and to stay competitive. However, they underlined the importance of parallel invest on human capital, improving crucial soft skills such as: openness to change, flexibility and the ability to work in a team, that could concretely support digital changes in procedures and work processes.
\end{abstract}

Keywords: knowledge management, Artificial intelligence, knowledge workers, organizational development.

(C) Manuti, Amelia; Monachino, Dalila, 2020.

This is an Open Access article distributed under the terms and conditions of the Creative Commons Attribution 4.0 International Licence (http://creativecommons.org/licenses/by/4.0).

East European Journal of Psycholinguistics, 7(2), 179-190. https://doi.org/10.29038/eejpl.2020.7.2.man 


\section{Мануті Амелія, Моначіно Даліла. Керування знаннями в добу штучного інтелекту: дослідження інформаційних працівників.}

Анотація. В еволюційному контексті промислової революції 4.0, де машинне навчання та технології передавання інформації від машини до машини - потужні інструменти підтримки та відтворення знань, впровадження гібридних систем, заснованих на використанні штучного інтелекту (ШІ), $€$ ключем до організаційних інновацій та капіталізації знань. Водночас, переваги цифрової трансформації для індивідів та команд невизначеність щодо майбутнього часто не є настільки очевидними, що часто призводить до страху у тих, хто зазнає впливу. Люди відчувають страх перед зміною своєї роботи, посади, втратою роботи, потребою вивчення нових навичок, технологій або нових методів роботи. Тому для забезпечення переходу на цифрові технології організації повинні надавати підтримку своїм кадрам, пояснювати, чому їм потрібно змінюватися. Із цієї перспективи, дослідження мало на меті дослідити, як висококваліфіковані інформаційні працівники здатні впоратися з новими реаліями. Проте учасниками дослідження була група менеджерів проєктів, зайнятих у компаніях зі сфери інформаційних технологій, де готові впровадити системи штучного інтелекту та цифрові технології для поліпшення відтворення, поширення та зберігання знань. Цих учасників вибрано з урахуванням їхньої важливої ролі в організації, оскільки керівників проєктів, як правило, розглядають як агентів змін. 3 огляду на вищевикладене, основним завданням було з'ясувати очікування та побоювання менеджерів проєктів щодо майбутньої інтеграції інформаційних потоків компаній зі стратегією автоматизації процесів. Було проведено серію індивідуальних інтерв'ю з використанням діатекстового аналізу дискурсивних даних. Результати засвідчили про наявність ідей і щодо ефективності менеджменту організацій, i щодо подальших досліджень. Учасники продемонстрували чітке усвідомлення необхідності «переходу на цифрові технології» для покращення організаційних показників та збереження конкуренції. Однак вони підкреслили важливість паралельних інвестицій у людський капітал, вдосконалення таких важливих м'яких навичок, як відкритість до змін, гнучкість та здатність працювати в команді, які могли б конкретно підтримати зміни в робочому процесі.

Ключові слова: керування знаннями, штучний інтелект, інформаційні працівники, розвиток організації.

\section{Introduction}

In the past sixty years, the introduction of information and electronic technologies has brought about a substantial change to production and business. Technological and social changes have intertwined in an indissoluble continuum in which our society has engaged in following this evolution by adapting to new practices and lifestyles. Similarly, to ensure their survival and competitiveness in the global market, organizations have profited from the advantages highlighted by the digital revolution and have rapidly learnt how to use technology specifically to capitalize their most precious resource: knowledge (Schilling, 2013).

Therefore, knowledge management has become a crucial process to adapt existing knowledge to business challenges, contextually studying new procedures to share and replicate knowledge. Knowledge Management nowadays aims to collect and manage knowledge connected to a company, eliminating redundancies and cognitive gaps, which can be created when the documentation remains separate between company departments. Artificial Intelligence systems are the most prominent new knowledge management procedures, being designed to facilitate company processes "replicating" mechanisms, normally adopted by human 
resources, to carry out company tasks immediately and efficiently (Amigoni, Schiaffonati, \& Somalvico, 2008).

Within the organizational contexts, knowledge is transferred, acquired, exchanged, discovered, generated and used in work (Davenport \& Prusak, 2000). In order to make this knowledge shareable with greater immediacy, it is therefore necessary to understand the forces that guide knowledge and the technologies that can be used as a support to its implementation and circulation (Davenport \& Prusak, 2000).

This change in the form and substance of Knowledge Management, however, may pose an obstacle for organizational processes whenever knowledge management is not supported by training activities and bottom-up change strategies addressed to reduce workers' resistance to change attitudes and behaviors.

Moving from these premises, the main aim of this study was to collect the expectations and fears of a group of high-qualified knowledge workers, namely project managers, and professional figures who coordinate project management activities in knowledge-based organizations. The choice of this special target of participants was addressed to outline the trends of digitalization in organizations, the human capital's perception with respect to the growing automation of the procedures and the best practices that could be introduced in the workplace to support the staff in the technological transition.

\subsection{Theoretical framework}

The fourth industrial revolution puts us in the face of a digital transformation process whose main objective is to provide the company with an organizational structure capable of rapidly and continuously introducing new technologies to support innovation in the field of knowledge sharing and replicability.

There is a spontaneous knowledge market within organizations, that is, what some economists call "near market", since many of the concluded transactions do not refer to formal contracts (Davenport \& Prusak, 2000). Sometimes, the sharing of knowledge within the "near market" can be cumbersome and complex, and this inefficiency could be overcome through the correct use of information technology, which is able to create infrastructures for the transfer of knowledge and information related to it (Schilling, 2013).

Among the several scientific contributions in the field, one of the most prominent one was provided by a study led by Prahalad and Hamel (2000) entitled Strategic Learning in Knowledge Economy: Individual, Collective and Organizational Learning Process. The authors explained how digitalization and the widespread diffusion of technologies could influence the sharing of knowledge in an organization. The core of Prahalad and Hamel's work was the development of a business model based on the capitalization of knowledge in terms of economical investments. The authors showed how the development of information technology and expert systems for knowledge management could be a distinctive value for the organization, increasing its competitiveness even in a fast-changing and turbulent socio-economic scenario like the present one (Prahalad \& Hamel, 2000). 
In this light, technology is proved to be an ally to those organizations who wish to transform themselves into knowledge systems to better manage the asset of data, information and knowledge possessed. However, this positive relationship between technology and performance is not simply a matter of economical investment and to invest in information technology could not be sufficient for organizations to obtain appreciable results (Davenport \& Prusak, 2000). What makes the difference is the ability of the organization to connect these investments to an organizational culture of knowledge management, that is having a clear plan of the knowledge that better serve to the organizational scopes and therefore that should be coded, shared and replicated. This will allow a to connect organizational knowledge to technological platforms and tools that could support knowledge circulation in relation with the organizational objectives (Seghezzi, 2015).

Knowledge, therefore, does not generate value automatically but as the result of the relationship between all the elements of the supply chain, from the manufacturer to the user. The basic idea that inspires this new managerial discipline is that each organization, within it, produces original and distinctive knowledge which, if properly valued, can contribute to the competitiveness of the company, nowadays thanks also to the help of technologies (Rullani, 2000; Parente, 2008). When talking about knowledge management technologies, generally the term knowledge management systems (KMS) recurs to underline that it is a category of information systems dedicated to the management of organizational knowledge or rather of architectures and IT applications developed to support and enhance KM processes.

In this perspective, knowledge management systems aim to make knowledge a controllable resource and to make knowledge a content that can be replicated and disseminated (Parente, 2008). Shared knowledges are propagated in the social communication network without being confined in too rigid material containers but becoming the object of a communication flow in which the tasks are carried out through the sharing of data and information (Parente, 2008).

Nonetheless, a knowledge management system should support communities and groups in the autonomous management of their knowledge, and parallel should favor interoperability processes between different communities (Boland, Tenkasi, Dov Te'eni, Bonifacio, \& Bouquet, 2002). This implies the configuration of a corporate knowledge network in terms of autonomous knowledge nodes that coordinate with each other, exchanging information using Artificial Intelligence (AI) and Machine Learning technologies and supports.

The use of these tools facilitates the acquisition, display, search and sharing of content and files, improving communication both within the work team and outside. Text mining and semantic research, self-learning technologies, cognitive computing, process-based methodologies for managing data flows, increasingly intuitive and social user interfaces, are the peculiar aspects of the new generation knowledge management platforms, at the basis of the digital workplace (Consoft Sistemi, 2019). 
Innovation management in terms of accompanying change, introduction of new practices, implementation of the replicability of knowledge and use of technological tools, supports knowledge management in pursuing the competitive advantage of organizations.

However, special attention must be paid not only to the hard components of the introduction of technologies in organizational contexts, but above all to the development of strategic knowledge management systems for human capital. There is no evidence of the real availability of individuals to share their knowledge through systems and infrastructures, until the device is built, and the reaction of the organization becomes observable. Therefore, the orientation towards digital evolution must be accompanied by a change in the organizational culture. The management should be aware that individuals, as knowledge repositories, are the key to the success of knowledge digitization procedures (Prahalad \& Hamel, 2000) and therefore should prepare human resources to embrace this radical transformation and to collaborate with it.

The company staff who work and deal with Artificial Intelligence is an interpreter called to make a real transition between one semiotic system and another. Whatever the degree of automation, Artificial Intelligence always includes the involvement of people: it is the Human-in-the-loop (HITL), the approach according to which machine and human being coexist within the same sense system, system that every innovation must be re-meaning, according to a typically human type of learning. The above approach is a philosophy of AI which focuses on creating workflows where an AI learns from the human operator while intuitively making the human's work more efficient (Amigoni, Schiaffonati, \& Somalvico, 2008). The Artificial Intelligence system based on the HITL approach learns from the feedback it gets and begins to serve human experts through increased quality and faster speed of executing operations. Processing operations and organizational actions through HITL systems therefore requires workers to be trained in learning new practices and managing change.

Therefore, strategic change management represents the core for effective digital oriented change. An inefficient infrastructure system is not the only cause of the failure of technological innovation, but the factors related to the corporate and individual culture, the relationship dynamics of the work team and the feelings triggered by the change can determine a disappointing economic and strategic effort (Gast \& Lansink, 2015). Participation and large-scale commitment by the workforce require, first, a solid knowledge of organizational culture and its social dynamics, in addition to understanding, from a psychological point of view, what determines the new behaviors in people who have to deal with change (Gast \& Lansink, 2015). Therefore, new management styles need to be adopted. The management should be capable of accompanying the staff through change, overcoming the feelings of bewilderment and uncertainty that could be generated and the consequent dynamics of resistance to change which, in the long run, would undermine the success of digitalization (Ahmad, 2014). 


\section{Materials and Methods}

The aim of this research was to investigate the expectations, fears, resistances and opinions of project managers and staff with a professional support framework for project management activities with respect to the orientation towards digital by organizations. The tool used to collect data was an individual in-depth semistructured interview built around some key thematic areas useful for research objectives.

More in detail, the topics addressed were: the contribution that digital devices can make to corporate knowledge management; the reasons why organizations are facing a structural change in procedures; the ways in which organizations are accompanying change; and the teams' perception with respect to the introduction of IT innovations in structured work processes. The complete outline of the interview is shown in the appendix.

Research participants were ten project managers: five men and five women, aged on average 38 years old. As for their organizational tenure, two of them had more than twenty years of working experience while three over ten years and five worked since less than ten years. The common feature to all participants was that they were employed in knowledge-based organizations, a quite new typology of organizations engaged in the knowledge management sector with the common goal of streamlining practices and procedures in order to reduce energy expenditure in terms of time, costs and resources.

The organizational contexts in which the participants operated were mostly immature as regards the integration of digitized procedures into secularized working practices, therefore, it was valuable to examine the expectations on the one hand, and the concerns, on the other, relating to the inclusion of Artificial Intelligence, cloud computing and machine learning technologies in structured work teams.

The research adopted a qualitative methodology to analyse the data. More specifically, a diatextual analysis of the narratives collected was performed adopting the SAM model, an acronym whose initials refer to salient aspects of the speech on which the analysis was based, namely the Subjectivity, the Argumentation and the Modality (Mininni, 2003). This model allowed scholars to analyze the identity profile of the enunciator by focusing on the use of these specific indicators and therefore reconstructing first of all the characteristics of "who says what", the network of arguments on which the subject bases his position and finally the ways in which this position is conveyed in the discourse with respect to the interlocutor, the object of discussion and the discursive context in which the relationship is placed (Mininni, 2003). The term "diatext", in fact, from the Greek "dia" or "through the text", recalls the dialectic and the dialogue of the co-construction of meaning that occurs in communicative events and in organizational contexts and is capable of highlighting the nature of the meaning as an organizational network of cultural units (Eco, 1975) and the intentional topic of linguistic action (Anolli, 2012).

Therefore, in relation to the objectives of this research, the choice of this methodology was guided by the awareness that the way in which participants 
discursively told their experience could be a significant indicator of the sense attributed to the management of digital change and the transformations of their own. role that guided behavior in the workplace. In concrete terms, among the diatextual markers useful for unveiling the discursive profile of speakers, this research has focused attention on the use of markers of agency, affectivity and meta-discursive markers.

\section{Results}

The qualitative explorative analysis performed using diatext as a tool to investigate participants' discursive strategies showed interesting results with special reference to project managers' attitude toward the digital change they were experiencing.

From a diatextual perspective, the mostly positive attitude toward digital change was constructed above all through the use of agency markers, such as "I", "we", "they" (Donzelli \& Fasulo, 2007). However, these discursive makers could have different functions within discourse. Sometimes they could be functional to mark the borders of discourse signalling competing positions (I versus they) about the object of discourse. The "I" is strategically used to create identification with the company (the ingroup) and a difference with the competitor (the outgroup) or with some most resistant employees. This is a common trait both in employees' (ex. 1, 3, 4) and management (ex. 2) discourses.

"I am smiling while hearing your question, because most companies say they are moving in this direction, but in my humble opinion, I think that they are switching to the digital because it is mostly a fashion (...)" (woman with twenty years of service seniority in HR and training consulting).

"We think that learning is a strategic asset, because being a company working with innovation it should be taken for granted that employees should update their expertise this is a prioirty for us to be competitive" (man wih twenty years of service seniority, CEO of a training consultuing).

"Yes, today we were studying the use of a portal that could simplify our (...) clearly this is a new phase for us" (man with over twenty years of seniority in training and financial consulting).

"(...) As a private company we must cross initiatives with social sustainability with those that are economically sustainable (...) (man with six years of service seniority in training consulting).

The personal pronouns "I"/'We" were also investigated as markers of affectivity, when used by participants while reporting their opinion on the subject under investigation. 
"I am technologically skeptical even though I have been working on it for twenty five years but compared to what you ask me I see only positive I think it has contributed" (woman with over fifteen years of service in training consulting).

"We are in favor of a learning model indicated as 70-20-10, i.e. in the workplace $70 \%$ of people learn from on the job training, $20 \%$ from expert colleagues and only $10 \%$ formal learning " (man with twentyfive years of service seniority in training consulting).

The analysis of some of these diatextual cues within the discourses collected allowed to point out two different rhetoric about digital transformation and knowledge management.

On the one hand, there was the "enthusiastic" rhetoric conveyed by the "digital natives", namely younger managers, who described technology as a precious tool to perform their tasks efficiently and transparently. Accordingly, they considered digitization as an integral part of the job.

"(...) is a tool that helps you with your tasks (...); we are young, we seek, we inform ourselves we try to introduce tools from below based on utility (...)" (male project manager with four years of service in gamification consulting).

"we are superconvinced that a cahnge could only have a positive impact also because we provide this kind of solutions to the companies, therefore we also use those technologies to train our employees" (man wih twenty years of service seniority, CEO of a training consultuing).

On the other hand, there was a "cautious" rhetoric conveyed by "mature managers", those aged between 40 and 50, who although perceiving innovation as a positive change, tended to undeline the need to take time to gradually "get used" to the change as long as technology use implies also "extra-work" to manage new processes.

"Immediately appreciated as an idea (...) (male project manager with over twenty years of service seniority in training and financial consulting);

(...) sometimes there are reworkings of the processes, I do it as I am used to and then it becomes digital, it is more an overload of work than a facilitation " (woman with seventeen years of seniority in HR and financial consulting).

\section{Discussion}

Results coming from this explorative diatextual study accounted for project managers' perceptions about digital innovation and change management and showed some interesting insights that could be used to plan future organizational development actions, addressed to a more efficient digitalisation of knowledge management. 
The first evidence referred to the widespread awareness of the participants involved that technological innovation is an unavoidable change mostly driven by external factors such as globalisation and competitiveness:

10) "(...) from the company's need to maintain a competitive advantage on the market. We are constantly looking for new methods and models especially applied to staff development because only in this way we can be competitive in a global market in which we participate as a company"(male project manager with twentyfive years of seniority in training consulting).

Furthermore, most organizational indications and prescriptions about digital innovation and change were top-down processes coming from the management and not fully shared with all workers. Moreover these changes were perceived as attempts to improve organizational performance and thus to reduce time and costs.

11) “(...) certain processes that have been streamlined and therefore have greatly shortened the time (...) the company does it is with a view to optimizing the timing and to ensure that you can do your job well and in the best possible time (...)" (male project manager with twentyfive years of service seniority in training consulting).

With respect to the topic of resistance to change, most participants remarked a double trend within the organizations, namely the convinced resistance manifested by more aged workers and the proactivity of younger colleagues:

12) "As usual in companies there are two factions that of the new entries, the young population who promotes the new tools and the elderly population, the veterans, who are reluctant to change" (male project manager with four years of seniority in race office).

With respect to the future, project managers were quite uncertain: some of them trusted the positive effects that technological innovation would produce: "we were super convinced that it is an improvement for the very fact that we provide solutions of this kind (...) (male project manager with six years of service in training consulting)", while others were more cautious since the direction of change is still unknown according to them "I am quite confident that it will propose new technologies (...)(female project manager with fourteen years of service seniority in training consulting)".

Therefore, if, on the one hand, the introduction of digitized knowledge sharing systems showed a significant reduction in terms of time and costs, on the other, a massive investment in terms of employees' training is required to overcome resistance to change.

Furthermore, according to some of the organizations involved in the study, there was an evident digital divide between digital natives and older workers, who showed uncertainties regarding the adoption of new working modalities and practices. In light with these results, most participants agreed about the central role played by some intangible dimensions of the person/organization relationship such 
as for instance identification, engagement and commitment to technological change. Therefore, organizations should invest in the construction of a common vision about technology that could be drive of positive organizational behavior and consequently could make training not only an economical investment rather an intangible but mostly precious capital for the actual trasformation of the working context.

\section{Conclusion}

The explorative results coming from the study highlighted the human dimension of organizations experiencing the digital revolution. This huge change has upset the organization of ordinary working practices as well as human resource management. This change is harder for those organizations basing their core business in knowledge management as long as their main drive is the intangible human capital of their employees and managers. This is the case of project management organizations. In force of this evidence, the study has contributed to give voice to some of these workers, shedding light on their resistances and on their attitudes toward technology and change, underlining the possible challenged that could hinder a positive transition to the digital. Furthermore, diatextual analysis allowed to catch these attitudes discourse showing the existence of two different rhetorics about technology acceptance: a cautious one versus an enthusiastic one. The first was best expressed by mature workers scared about the possibility to attune with the radical and rapid changed imposed by digitization, the second voiced by digital natives, namely by the younger generations who are familiar with the use of technology also beyond the professional domain. However, although challenging in terms of human resource management practices this opposition could be turned into an opportunity to exploit informal training across generation creating for instance virtual communities of practices sharing knowledge and expertise and showing the benefits of using technology for the sake of the organization. By this, mature workers could be ambassadors of the organizational culture for the younger colleagues who in turn could be coaches to them supporting their transition to the digital. Certainly, the top management should be aware about these dynamics and should share the cultural project behind these training practices. Change is not possibile without the convinced commitment and sponsorship of the so-called agents of change, namely the managers, who can transform what could be perceived as a threat into a real opportunity.

\section{References}

Ahmad, S. (2014). Technology in organizations. International Journal of Research in Business Management, 2(7), 73-80. http://doi.org/10.5958/22497315.2016.00322.1.

Amigoni, F., Schiaffonati, V., \& Somalvico, M. (2008). Enciclopedia della Scienza e della Tecnica, Rome: Treccani.

Ankrah, E., \& Sokro, E. (2012). Human Resource Information System as a Strategic tool in Human Resource Management, Central University College, Ghana. 
Anolli, L. (2012). Fondamenti di Psicologia della Comunicazione, Il Mulino, Bologna.

Bandini, S. (2008). Knowledge Management L'eredità Dei Sistemi Esperti. Mondo Digitale, 3, 27-37. Retrieved from: http://archivio-mondodigitale.aicanet.net/Rivista/08_numero_3/Bandini \%20p. \%202737.pdf

Barney, J.B. (2006). Risorse, competenze e vantaggi competitivi. Manuale di strategia aziendale. Rome: Carocci.

Birzniece, I. (2011). Artificial Intelligence in Knowledge Management: Overview and Trends. Applied Computer Systems, 43(1), 5-11. https://doi.org/10.2478/v10143-011-0001-x.

Boland, R., Tenkasi, R., \& Dov Te'eni. (1994). Designing information technology to support distributed cognition. Organization Science, 5(3), 456-475. https://doi.org/10.1287/orsc.5.3.456.

Bonifacio, M., \& Bouquet, P. (2002). Enabling Distributed Knowledge Management. Managerial and Technological Implications. Upgrade, 3(1), 1-7. $\quad$ Retrieved from: https://www.researchgate.net/publication/2487632_Enabling_Distributed_Knowledge_Man agement_Managerial_and_Technological_Implications

Chang Lee, M., (2016) Knowledge management and innovation management: Best practices in knowledge sharing and knowledge value chain. International Journal of Innovation and Learning, 19(2), 206-226. https://doi.org/10.1504/IJIL.2016.074475

Consoft Sistemi (2019). L'intelligenza Artificiale al servizio dell'uomo. Dalla cybersecurity alla cooperazione allo sviluppo, criticità e punti di forza della tecnologia del futuro, Digital Transformation per lo sviluppo sostenibile. Retrieved from: https://www.consoft.it/it/

Crismore, A., Markkanen, R., \& Steffensen, M. (1993). Metadiscourse in persuasive writing: A study of texts written by American and Finnish university Students. Written Communication. 10(1), 397. https://doi.org/10.1177/0741088393010001002

Davenport, T.H., \& Prusak, L. (2000). Il sapere al lavoro: come le aziende possono generare, codificare e trasferire conoscenza, ETAS, 31-64.

Donzelli, A., \& Fasulo, A. (2007). Agency e linguaggio. Etnoteorie della soggettività e della responsabilità nell'azione sociale, Booklet, Milan.

Eco, U. (1975). Trattato di semiotica generale, Bompiani, Milan.

Gast, A. \& Lansink, R. (2015). Digital hives: Creating a surge around change. McKinsey Quarterly. Retrieved from: https://www.mckinsey.com/business-functions/organization/our-insights/digital-hivescreating-a-surge-around-change

Maci, L. (2018). Che cos'è l'Industria 4.0 e perché è importante saperla affrontare, EconomyUp, Milan.

Magone, A., Mazali, T., \& Segantini, E. (2016). Industria 4.0, uomini e macchine nella fabbrica digitale, Guerini e Associati Edizioni: Milan.

March, J.G., \&Simon, H.A. (1958). Organizations, John Wiley \& Sons, NY.

McAdam, R. (2000). Knowledge management as a catalyst for innovation within organizations: a qualitative study, Knowledge and Process 
Management - The Journal of Corporate Transformation, 7(4), 233-241. https://doi.org/10.1002/1099-1441(200010/12)7:4<233::AID-KPM94>3.0.CO;2-F.

Mininni, G. (2003). Il discorso come forma di vita, Guida, Naples.

Nonaka, I., \& Takuechi, H. (1995). The Knowledge Creating Company. Oxford University Press, Oxford.

Parente, R. (2008). Co-Evoluzione e cluster Tecnologici, Aracne, Rome.

Prahalad, C.K., \& Hamel, G. (2000). The Core Competence of the Corporation. In Cross R.L., Israelit S.B. (Eds.). Strategic Learning in Knowledge Economy: Individual, Collective and Organizational Learning Process. (pp.3-22). Butterworth Heinemann, Boston,

Rajan, A., Lank, E., \& Chapple, K. (1999). Dalla cultura individuale alla cultura organizzativa: favorire la creazione e lo scambio di conoscenze, ITER, Rome.

Rullani, E. (2000). Sistemi locali e produzione di conoscenza, relazione al Convegno Ocse su Enhancing the Competitiveness of Smes in the Global Economy: Strategies and Policies, Bologna.

Schilling, M. (2013). Gestione dell'Innovazione, McGraw Hill, Milan.

Seghezzi, F. (2015). Come cambia il lavoro nell'Industry 4.0?, Working Paper ADAPT, DAPT University Press.

Serrat, 0. (2017). Building a Learning Organization. In Knowledge Solutions. (pp. 57-67). Springer, Singapore.

Zanzotto, F.M. (2019). Viewpoint: Human-in-the-loop Artificial Intelligence, Journal of Artificial Intelligence Research, 64, 243-252. https://doi.org/10.1613/jair.1.11345.

\section{Appendix}

\section{Interview}

1. Which company do you work for and which is your role?

2. Which is your job role seniority?

3. Gradually the use of Artificial Intelligence (AI) systems is involving many business areas, in particular that knowledge sharing. In your opinion, can AI be a support for knowledge management in the organizational context?

4. Can digitalisation favor or hinder the circulation of company knowledge in your opinion?

5. Is your company facing these changes? If so, how? If not, why?

6. Which challenges are emerging from the automation of some working procedures?

7. How did work teams in your organization are reacting? Are they actively promoting change or are they undergoing this situation? Are they resisting to change or not?

8. Is this transition, from a knowledge management by word of mouth or paper and pencil to a diffusion of knowledge through AI technologies, causing changes in work organization in your opinion?

9. During this transition between traditional to digital knowledge management, is the staff being accompanied through training activities?

10. Which skills do you think are needed in a team to manage and deal with these changes?

11. Are there already procedures in which the use of automation is securing higher effectiveness and efficiency to the organization?

12. Is your organization planning further changes in the direction of AI? 